\title{
Translation and Social Ideological Trends in the Late Qing Dynasty
}

\author{
JIANG Shiyang \\ College of Foreign Languages, Jishou University, China
}

Received: July 22, 2021

Accepted: November 26, 2021

Published: January 31, 2022

To cite this article: JIANG Shiyang. (2021). Translation and Social Ideological Trends in the Late Qing Dynasty. Asia-Pacific Journal of Humanities and Social Sciences, 1(4), 119-125, DOI: 10.53789/j. 1653-0465. 2021.0104.015

To link to this article: https://doi. org/10.53789/j. 1653-0465.2021.0104.015

\begin{abstract}
As a social and cultural activity, translation to some extent is the "barometer" of social, ideological trends, and translation activities are greatly influenced and restricted by social movements. In the last years of the Qing Dynasty, the four movements happened subsequently, i. e., "the movement of using the barbarians' skills to deal with barbarians", "the movement of enforcing the army and enriching the country", "the movement of carrying out constitutional reforms" and "the movement of enlightening people". Translation as an essential cultural representation in the late Qing Dynasty reflected the theme of saving the country in translation organizations, translation subjects, and selections of original texts.
\end{abstract}

Keywords: translation; late Qing dynasty; social ideological trends

Notes on the contributor: JIANG Shiyang is a MTI student at the College of Foreign Languages, Jishou University, China. Her academic interest lies in translation theories and practice and corpus-based translation studies. Her email address is545831359@qq.com.

\section{Introduction}

Since the Opium War (1840-1842), translation had become an effective way for Chinese people to learn from the West and save the country. It had distinctive characteristics of its own. Facing the national crisis of foreign aggression, a group of progressives who worried about the country were engaged in the cause of saving the country. In addition to cultivating early scientific talents, they actively promoted translation. They disseminated Western knowledge of natural science, philosophy, and social science, thus creating a climax of learning from the West in the history of modern translation (Wang, 2005: 22).

\section{Translation in Late Qing Dynasty and "the Movement of Using the Barbarians' Skills to Deal with Barbarians"}

The Qing Dynasty implemented such a "closed-door policy" prior to the Opium War of 1840 that people 
were long kept in the dark about the West. Consequentially, they neither knew the geographical locations of the foreign countries nor the foreign countries' politics. Xu Jiyu, an official and scholar, commented on the situation at that time, "people usually avoided talking about the great things overseas. When the warships struck, people were scared to death. (Tian, 1999: 47)" Britain defeated China in the Opium War owing to its clumsy weaponry and archaic theory of pre-modern warfare. Chinese people "might hear about Great Britain, but did not know where it was. (Chen, 2002: 328)" In order to "know ourselves as well as the enemy", some Chinese people, represented by Lin Zexu, a minister of the Qing Dynasty, and Wei Yuan, a thinker, and statesman put forward the policy of "using the barbarians' skills to deal with barbarians". They also organized people to translate and publish books on politics, economy, geography, and history of Western countries.

In order to resist Western aggression, Lin Zexu organized the translation of Western newspapers and magazines and at the same time learned Western knowledge, thus becoming a pioneer in learning from the West in the modern history of China. During the opium ban in Guangzhou, he set up a translation academy. He often inquired about Western events, translated Western books, and bought newsprint daily (Liang, 1989: 323-324). Lin Zexu's active participation in translation activities was actually for the needs of anti-opium and anti-Britain. Thus he compiled various books, such as Si Zhou Zhi (World Knowledge), Hua Shi Yi Yan (China's Affairs in the Words of Foreigners), Law of Nations. In order to enforce armament and let the army master the method of using artillery, Lin Zexu also organized the translation of Western books on the manufacture of firearms and operating instructions of heavy artillery.

Wei Yuan, a close friend of Lin Zexu, also has contributed to the translation of Western books. Based on Si Zhou Zhi, he compiled Hai Guo Tu Zhi (the Oceanic Countries with Illustrations). Wei Yuan stated in the "preface" that his purpose in compiling this book is to get insight into the enemy, enforce the army and study diplomatic knowledge, and finally achieve the goal of "using the barbarians' skills to deal with barbarians". This book, chronicling the world circumstances before and after the Opium War, plays a vital role in understanding the Western countries and broadening Chinese people's horizons. It exerts far-reaching effects not only in modern China but also in Japan during the Meiji Period. In addition, Xu Jiyu also made contributions to the translation of Western books. In order to improve Chinese people's awareness of the "vast territory of the overseas countries", he extensively collected foreign materials, maps, and booklets, read various history books and compiled them into Ying-huan Chi-lue (World Geography). This book provides a detailed introduction to the territory, race, population, history, property, customs, religions, and other aspects of various countries in the world, which significantly broadened Chinese people's horizons. Liang Qichao, a famous thinker and statesman, held that "the Oceanic Countries with Illustrations and World Geography are now rarely read, but the Chinese literati's knowledge about the world begins with these two books. (Materials on Modern Chinese History Series, 1961: 18)"

Lin Zexu and Wei Yuan, as the progressives in Western learning, proposed the idea of "using the barbarians' skills to deal with barbarians". Although the idea has not been practically implemented and the translation books are restricted in Western history and geography, their translation activities and propositions reflect the real needs of the late Qing Dynasty. What they did has become the beginning of studying Western culture, exerting inspirations and influences for the latecomers to explore the nation's road. 


\section{Translation in Late Qing Dynasty and "the Movement of Enforcing the Army and Enriching the Country"}

In the early 1860s, the Qing Dynasty was in peril under the peasant uprisings of the Taiping Rebellion (1851 $-1864)$ and the invasion of the British-French allied forces. Such a turbulent situation made some bureaucrats realize that "China is facing an unprecedented change for thousands of years" and "the Western powers are powerful enemies that China has not confronted for thousands of years". Then, to resist invasion through self-reliance, the "Westernization Movement" (1861-1894) began to exert influence in the political field. Guided by the thought of "absorbing Western technology based on the Chinese system", the Westernization Group has taken the founding of military-civilian enterprises, establishing Western-style schools and training of foreign language talents as means of becoming strong and seeking prosperity. The Westernization Group knew that to maintain the military industry and civilian enterprises, they had to master advanced science and technology. Therefore, it was imperative to learn from the West through translating Western books. Zeng Guofan, a statesman and famous official, pointed out, "translation is the foundation of manufacturing. Foreigner-made machines are based on arithmetic, and the manufacturing principles and methods can be found in the illustrations or manuals. If we do not understand foreign languages, we would never know how the machine was manufactured". (Liang, 1999: 83)

In 1862, Yi Xin, a late Qing statesman, established the Beijing Tongwen Academy (the first official foreign language school in the late Qing Dynasty) to cultivate qualified translators for foreign affairs. The academy successively set up the English Hall, French Hall, Russian Hall, German Hall, and Japanese Hall. In 1863, Li Hongzhang, a statesman and diplomat, suggested the establishment of the foreign language school in Shanghai, namely the Shanghai Foreign Language and Literature School (incorporated into the translation hall of Jiangnan Bureau of Manufacturing in 1869). Guangzhou Tongwen Academy, Mawei Shipyard Academy (also known as Fujian Shipyard Academy) were also established in 1864, 1866 respectively. As the prominent institutions for disseminating Western scientific knowledge and technology, these academies trained qualified translators and cultivated diplomatic and scientific personnel. The Beijing Tongwen Academy boasts the most significant number of translated books. The essential books are The Law of Nations, Code Napoleon, The Statutes of Singapore, Manual of Political Economy, Public Law Association, Elements of Astronomy, History of Russia, etc. From the above, it can be seen that the books translated by Tongwen Academy are mainly international laws and the laws of various nations. This indicates that after the Opium War, the closer diplomatic contact with the Western countries forced the Qing government to learn the laws of various countries.

The Translation Academy of Jiangnan Manufacturing Bureau made the most significant contribution to the translation of Western books. Because of the urgent need for practical knowledge on gunpowder, gun technique, and steam turbine, the initial translation books are about the steam turbine, modeling technology, casting technology, Gatling gun, Krupp gun, and other ordnance technology. In addition to these applied science books, the academy also translated several natural science books, including math, electricity, chemistry, and hydraulics, such as The Elements (the last nine volumes), An Elementary Treatise on Mechanics, Outlines of Astronomy, translated by Li Shanlan. According to a bibliography written by British missionary John Fryer in 1880, among the books translated before 1880, there were 24 books on navy and infantry strategies, 21 books on the manufac- 
turing process, 10 books on the steam turbine, 24 books on mathematics, 12 books on astronomy, 6 books on chemistry, 5 books on geology, 8 books on geography and 10 books on natural science. Compared with natural science, books on the military occupy a more significant proportion of the translation books. When Liang Qichao analyzed why the books on military strategies had counted almost half of the total, he said, "after a series of failures, China realizes that Westerners are extremely powerful in military weapons and strategies. We hope to learn from the advanced industries and weapons of the Western powers to fight them, so the books were mainly focused on the military. (Zheng, 1987: 578)"

During the Westernization Movement period, the selection of translation texts focused on making the country more prosperous and powerful. The translated books had an important influence, which played a special role in the urgent need of the Qing Dynasty and disseminated scientific and technological knowledge. However, restricted by the social situation and narrowed cognition, the translated books emphasized applied science and natural science too much. Nevertheless, the Westernization Group's translation books reflect the idea of "using the barbarians' skills to deal with barbarians" and the resolve in finding a way to save modernized China through science \& technology and industrialization.

\section{Translation in Late Qing Dynasty and "the Movement of Carrying out Consti- tutional Reforms"}

The Westernization Movement, however, did not save China in distress. Failed in the Sino-Japanese naval battle in 1894, China was forced to sign the humiliating Treaty of Shimonoseki, which unprecedentedly intensified the national crisis. The situation in China after the Sino-Japanese War of 1894-1895, as Kang Youwei said, was like "falling asleep on fire". China was in jeopardy because such world powers as Russia, England, France, and Japan were casting a greedy eye. Such a critical situation has stimulated some rulers and patriotic intellectuals to fight against foreign invasion and carry out reforms. Then, the Chinese bourgeois reformists have appeared in Chinese history.

The reformists believed that translating Western books was the first step to save the country, reform, and learn from the West. Therefore, from 1894 to 1900, the reformists founded and published newspapers and magazines, established translation agencies, and translated numerous Western books, much more significant in scale and more prosperous content than the Westernization School. In addition, compared with the books in the Westernization period, the translation books have changed in the reform period. Before the Sino-Japanese War of 1894-1895, influenced by the ideology of "Chinese essence and Western means", translation books mainly focused on applied science and natural science.

To meet the needs of the reform during the Westernization Movement period, the reformists advocated that original texts of translation should mainly focus on Western social sciences such as politics, economy, law, and history, especially the books in politics and law. Liang Qichao said, "politics and law are the foundation of a country. Japan's reforms have first changed its roots, while China's reforms have not worked under the roots. Both are reforms, but the results are completely different. The current solution is to translate the foreign countries' law, civil law, business law, and criminal law. (Chen, 1992: 162)" He also claimed that the books that Datong Translation Bureau translated should prioritize politics and the arts. According to the incomplete sta- 
tistics, the translation of social science books on politics and law reached several 136 in the three years from 1902 to 1904, ranking first in the various translation books (Wang, 2000: 416). This indicates that the selections of original texts are closely related to the political ideology, reflecting the intellectuals' interest in China's institutional reform.

In the Sino-Japanese War, the Beiyang Fleet, equipped with advanced guns, was brutally defeated by Japan - a tiny country. The patriots were shocked to discover that Japan was rising abruptly. Complete westernized Japan defeated incomplete Westernized China, eloquently proving the practical effect of Western learning. Then, the Chinese government's perception of Japan has changed. Some believed that if China wants to learn from the West, it is better to first learn from Japan. Kang Youwei suggested emperor Guangxu twice in 1898, "requesting to translate extensive Japanese books, sending large groups of students to study world knowledge to cultivate competent persons" (Tang, 1981: 301). Liang Qichao also advocated learning from Japan, "Japan had developed rapidly because of learning from the West. Now we should learn from today's Japan. By observing and analyzing Japan's reform, we could achieve our goals in three years since the valuable books of various disciplines in the West have been translated by Japan. Comparing the Western countries as the cattle, Japan as the farmer, we do not need to spend thousands of dollars collecting valuable books". Therefore, he advocated that translation should "mainly focus on Eastern books and supplemented Western books". With the strong advocacy of Kang Youwei and Liang Qichao, the upsurge in the translation of Japanese books and Western books directly through Japanese was launched in the late Qing Dynasty. According to statistics, of the 533 Chinese translation books from 1902 to 1904, there were 321 books from Japanese, accounting for 60\% of the total (Wang, 2000: 415). Japan has become an important transfer station for Western learning in the late Qing Dynasty.

After the Sino-Japanese war, the reformers linked the translation to the national salvation and reformation, giving translation books modern and contemporary significance. The translation books were related to institutional reform. It not only conforms to the prevailing political situation and the needs of the times but also reflects that people's cognition had promoted from the "object-level" to the "ideology level".

\section{Translation in Late Qing Dynasty and "the Movement of Enlightening Peo- ple"}

The Reform Movement of 1898 (led by Kang Youwei and Liang Qichao) soon ended with the Coup of 1898 (Wuxu Coup), announcing the failure of the political reform movement. After the failure of "One Hundred-Day Reform", Kang Youwei and Liang Qichao realized that they could not save and rejuvenate the country through reform. In their view, China's road to a strong country requires a strong military and a robust system. More importantly, it must enlighten people and raise their awareness to strengthen and enrich the country. Therefore, the movement "enlightening people" was prioritized by the reformers.

Reformers thought fiction was the most accessible and effective way to enlighten people. Yan Fu and Xia Zengyou stated in a book in 1897, "people's thoughts and customs, are mostly affected by the Confucian classics and the books about history". Kang Youwei also said in The Bibliography of Japan, "those literate people may not have read the scriptures, but they must have read novels. (Kang, 1989: 13)" Liang Qichao pointed out that the novel possesses "an incredible power which can dominate humanity". He regarded novels as "the best of lit- 
erature" (Liang, 1989: 34-35). However, traditional Chinese novels are mostly "seducing people to commit crimes", which is "the root of corruption". In contrast, as authentic literature, Western novels are closely related to politics or the public, which is beneficial to national progress. Therefore, the reformers unanimously advocated translating foreign novels. Kang Youwei appealed that "the foreign novels should be translated and studied as soon as possible". Liang Qichao also said: "What we should translate are those valuable books related to the current Chinese situation". With their vigorous advocacy, a wave of translation of foreign novels emerged in China in the late 19th and early 20th centuries.

The bourgeois revolutionaries led by SunYat-sen, a great democratic revolutionary, had witnessed the corruption and incompetence of the Qing government from the failure of the Reform Movement of 1898 and the Peace Treaty of 1901. They decided to overthrow the Qing government through armed struggle and established an independent country. Therefore, the bourgeois revolutionaries widely spread public opinion through translating and publishing books and magazines that introduced the bourgeois-democratic thoughts, such as the Law of the Rousseau on the Treaty of Johno, La Liberté, and Republican Government Theory. These translation works have played an essential role in promoting national awakening and revolution, which enabled the Chinese bourgeois revolutionaries to obtain advanced Western ideological weapons. A growing number of people participated in the revolution, which significantly contributed to overthrowing the Qing Dynasty's feudal rule in 1911.

\section{Conclusion}

Modern China is a time of saving the country and enlightening people. China's modern translation is also restricted by the times. Unlike the translation of Buddhist scriptures and science \& technology, the translation in the late Qing Dynasty was closely related to politics and the country's destiny. Facing the national crisis, the modern Chinese patriotic intellectuals take translation to save the country, which coincides with social changes. In short, the translation activities in modern China, to some extent, reflect the people's awareness to strengthen and enrich the country. It is a vivid portrayal of the national awakening, and it indeed records the struggle of the Chinese people who are unwilling to surrender. They sought truth and explored the way out for the country, which provided helpful inspiration and experience for the successors.

\section{References}

CHEN Pingyuan \& XIA Xiaohong. (1989). Theory of Chinese novels in the 20th century (1897-1916). Beijing: Peking University Press.

CHEN Fukang. (2002). A history of translation theory in China. Shanghai: Shanghai Foreign Language Education Press, 328.

CHEN Xiaoyu. (1992). Metabolism of modern Chinese society. Shanghai: Shanghai People's Publishing House, 162.

HUANG Jiaofeng. (2021). Is Mohism a religion? Reflection on "Mohism” in Mohist studies. Asia-Pacific Journal of Humanities and Social Sciences, 1(2), 48-57.

JIANG Lin. (2021). Liang Qichao's translation: the making of modern Chinese fiction. Asia-Pacific Journal of Humanities and Social Sciences, 1(1), 1-14.

LIANG Qichao. (1989). Work collection of master of Yinbing study. Beijing: Zhonghua Book Company, 323-324.

LIANG Qichao. (1999). Work collection of Liang Qichao. Beijing: Beijing Press, 83.

Materials on modern Chinese history series (1961). The Westernization Movement (IV). Shanghai: Shanghai People's Publishing 
House, 18

TIAN Hailin. (1999). History of political thoughts in modern China. Shandong: Shandong University Press, 47.

TANG Zhibiao. (1981). Political theory of Kang Youwei. Beijing: Zhonghua Book Company, 301.

WANG Bingqin. (2005). The Ideological history of translation in the 20th century. Tianjin: Nankai University Press, 22.

WANG Xiaoqiu. (2000). History of modern Sino-Japanese cultural exchange. Beijing: Zhonghua Book Company, 416.

WANG Xiaoqiu. (2000). History of modern Sino-Japanese cultural exchange. Beijing: Zhonghua Book Company, 415.

ZHENG Zhenxi. (1987). Selected works of the late Qing dynasty. Shanghai: Shanghai Book Bureau, 578.

( Editor: JIANG Qing) 